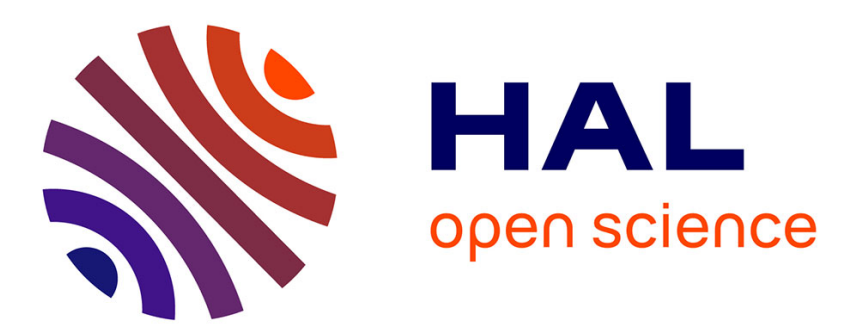

\title{
Preliminary results of fish population distribution in a Senegalese coastal area with depths less than $15 \mathrm{~m}$, using acoustic methods
}

\author{
Jean Guillard, A. Lebourges
}

\section{- To cite this version:}

Jean Guillard, A. Lebourges. Preliminary results of fish population distribution in a Senegalese coastal area with depths less than 15 m, using acoustic methods. Aquatic Living Resources, 1998, 11, pp.13-20. hal-02686348

\section{HAL Id: hal-02686348 \\ https://hal.inrae.fr/hal-02686348}

Submitted on 1 Jun 2020

HAL is a multi-disciplinary open access archive for the deposit and dissemination of scientific research documents, whether they are published or not. The documents may come from teaching and research institutions in France or abroad, or from public or private research centers.
L'archive ouverte pluridisciplinaire HAL, est destinée au dépôt et à la diffusion de documents scientifiques de niveau recherche, publiés ou non, émanant des établissements d'enseignement et de recherche français ou étrangers, des laboratoires publics ou privés. 


\title{
Preliminary results of fish population distribution in a Senegalese coastal area with depths less than $15 \mathrm{~m}$, using acoustic methods
}

\author{
Jean Guillard ${ }^{\left(1^{*}\right)}$, Anne Lebourges \\ (1) ORSTOM - CRODT, BP 2241, Dakar, Sénégal. \\ (2) ORSTOM, Institut Océanographique, 195 mue St Jacques, 75005, Paris, France. \\ E-mail: lebourge@orstom.orstom.fr
}

Received December 9, 1996; accepted September 29, 1997.

\begin{abstract}
In order to manage the fish stock of the Senegal coastal zone it is necessary to carry out direct assessment surveys by acoustic methods. Acoustic surveys were carried out in this region from a sports-fishing boat, using a split-beam echo sounder in vertical mode, in areas with depth less than $15 \mathrm{~m}$. On a short time scale, spatial structure of the fish population remained stable. The average acoustic biomass detected was variable, but we observed a relative stability of target strength distribution of single fish. The use of acoustic methods in these areas of shallow depths, the consequences of escape behaviour of the fish, and sampling strategies are discussed. $\odot$ Ifremer-Elsevier, Paris
\end{abstract}

acoustic survey / shallow waters / target strength / multi-beam sonar / Senegal.

Résumé - Résultats préliminaires de la répartition des populations de poissons dans la zone côtière du Sénégal sur des fonds inférieurs à $15 \mathrm{~m}$, par des méthodes acoustiques. Des campagnes d'estimation du stock de poissons, utilisant des méthodes acoustiques, ont été réalisées dans la zone côtière du Sénégal sur des fonds inférieurs à $15 \mathrm{~m}$, à partir d'un bateau de pêche sportive, au moyen d'un sondeur à faisceau scindé utilisé en mode vertical. Sur une courte échelle de temps, les structures spatiales des populations de poisson semblent stables. La quantité de poisson détectée est variable, mais on observe une relative stabilité des distributions des indices de réflexion des poissons individuels. L'utilisation des méthodes acoustiques dans ces zones peu profondes, les conséquences des comportements de fuite des poissons, ainsi que les stratégies d'échantillonnage sont discutées. $\odot$ Ifremer-Elsevier, Paris

acoustique / eaux peu profondes / indice de réflexion / sonar multi-faisceaux / Sénégal.

\section{INTRODUCTION}

In Senegal, coastal pelagic fish account for more than $80 \%$ of the artisanal fishery catches and this resource is increasingly exploited [1]. Data analyses are based on fishery statistics and direct biomass evaluations by acoustic methods. The artisanal fishery uses beach seines, but fisheries data are too fragmentary to be applicable for precise stock evaluation. For more than 10 years, acoustic surveys have been carried out to estimate the biomass of pelagic fish, and to map fish population distribution [19]. Shallow waters, less than $15 \mathrm{~m}$ deep, are missed in these evaluations, as oceanographic ships can not operate in such waters. Nevertheless, a substantial portion of the fish biomass can be found on the coastal fringes which sometimes extend more than 10 nautical miles from the coast.

The main part of the Senegalese small coastal pelagic fish exploitation is the M'Bour area. Additionally, this region is considered as a reproduction and nursery zone [1]. The main types of fish in the region are small pelagic fish like Sardinella aurita, (Clu-

\footnotetext{
${ }^{\left({ }^{*}\right)}$ Correspondence address : INRA, BP 511, 74203 Thonon cedex, France (e-mail: guillard@ thonon.inra.fr)
} 
peidae), Trachurus trecae, and Trachurus trachurus (Carangidae). Sardinella aurita migrate seasonally North - South, depending on their reproductive cycles which peak in May - June and October - November [5]; on the contrary Sardinella maderensis is more sedentary. The juveniles stay in the nursery zones for a year before migrating. Migration charts and zones of concentration have been identified [2].

The use of acoustic methods in shallow waters (depth $<15 \mathrm{~m}$ ), though still unusual, is increasing [9] $[11,10,3]$. Acoustic surveys were undertaken in M'Bour area, in depth less than $15 \mathrm{~m}$, and done monthly from December 94 up to August 1995. After a description of the material, and of the sampling strategies, results of the surveys are provided. Two types of results were obtained: acoustic biomass and target strength (T.S.) distributions of the fish populations, both in relative rather than absolute terms, because of the preliminary nature of this study. It is our aim to increase the knowledge about the fish stock distribution, give the difficulties and technical limitations of acoustic methods in shallow waters $[9,11]$.

\section{MATERIAL AND METHODS}

The experiments were carried out from a sport-fishing boat equipped with a Global Positioning System. Its draught allows navigation in shallow depths. The acoustic device used was a SIMRAD EY500 splitbeam echo sounder, frequency $120 \mathrm{kHz}$, circular transducer, total beam angle $9.1^{\circ}$ at $-3 \mathrm{~dB}$, pulse length $0.3 \mathrm{~m} \cdot \mathrm{s}^{-1}$, Time Varied Gain amplifier, TVG $20 \log \mathrm{R}$ and $40 \log \mathrm{R}$. Power was supplied from the boat electric batteries. The transducer was rigidly fixed at the right side of the boat between $0.50 \mathrm{~m}$ and $1.50 \mathrm{~m}$ below the surface for vertical mode emission. The $2 \mathrm{~m}$ depth layer below the surface was ignored (the surface - transducer distance, then the blind transducer zone) [13]. During each survey, calibrations were carried out by using a standard $120 \mathrm{kHz}$ copper sphere, with the standard protocol recognised by Foote et al. [4], and the procedure defined by the EY500 sounder manual (SIMRAD, 1994). A calibration procedure was done in an experimental basin before the first survey. In addition, noise measurements at sea were carried out as recommended by the EY500 manual. The data were processed using SIMRAD EP500 analysis software, which generates results in echo integration units in $\mathrm{m}^{2}$. nautical mile ${ }^{-2}$, for the integrated echoes (termed Sa by SIMRAD). This is the acoustic biomass in terms of "area" reflected and has not been transformed to biomass in weight units. This is because the correction factor, the mean acoustic cross section per fish, was difficult to calculate in a multi-species environment whose species composition varied throughout the season. Furthermore, for the purpose of this paper it is not necessary to do so, as only relative biomass are required. Concerning biomass calculations, the threshold was set at $-55 \mathrm{~dB}$. These levels were chosen during readings in order to avoid ambient noises, and to only take fish into account. Careful scrutiny of the echograms was undertaken to ensure that only fish were considered, in situ and by replaying echograms. Single fish discrimination was done using EY500 parameters, recommended in noisy conditions. The single fish T.S. minimum value was fixed at $-50 \mathrm{~dB}$. To accept a target as a single fish, the maximum number of consecutive missing pings in a track was set at one ping, and the minimum number of consecutive track was set at two pings. Only surveys with more than 100 single fish observed were analysed.

\subsection{Sampling strategies}

Eleven sampling surveys were carried out over identical courses, night and day, from December 1994 to August 1995. Surveys were made monthly, only when weather conditions were approximately identical, i.e. moderate rough seas. The procedure was as follows: surveys started at $2-3 \mathrm{~m}$ depth, at about 4 p.m., and were run at a constant speed of about 4 knots towards the open sea. Every 15 min (1 nautical mile) direction was changed, at first parallel to and then perpendicular to the coast. We returned to shore when $15-20 \mathrm{~m}$ depths were reached. The survey ended normally between 2 and 4 a.m. The forth and back trips were often quite different due to currents. The sample length echointegration units, a sequence, i.e. the distance over which the echo integral is accumulated to give one sample, was 0.1 nautical mile.

To describe spatial distribution of fish biomass, $1 / 2$ variograms [18] were calculated for each survey [20]. The variogram measures the mean quadratic deviation between two points separated by a vectorial distance, $h$, and describe the spatial structures of the variable at different scales [26].

\section{RESULTS}

\subsection{Estimates of acoustic biomass from split-beam data}

The results of different surveys are presented on maps of detected biomass in echointegration units $\left(\mathrm{m}^{2}\right.$. nautical mile $\left.{ }^{-2}\right)$. The sample length echointegration units are represented by proportional circles to observed acoustic biomass, centred on the middle of each sequence (figure 1). The shape of the histograms of biomass values (figure 2) is classical $[13,14]$. Whatever the season, the histograms have a high percentage of low or zero biomass sampling units, and a very long distribution tail-off. The proportion of zero values varies very little $(<10 \%)$ apart from the March surveys, when the percentage was as high as $25 \%$. This low number of sequences without detection means that fish are distributed in the whole area. The extreme values to the right correspond to fish schools. Schools are 
detected in all seasons, generally in small numbers, except in February where the number is great.

Estimation (arithmetic mean \pm SD ) of acoustic biomass $\left(\mathrm{m}^{2}\right.$. nautical mile $\left.{ }^{-2}\right)$ was calculated for the total number of runs of each survey (forth and back). Table I recapitulates results survey by survey. The coefficient of variation (standard deviation divided by mean) is always greater than $80 \%$. The mean detected acoustic biomass varies from 0.04 to 3.13 echo integration units (figure 3). Between two consecutive courses (forth and back) a Wilcoxon test allows the affirmation that there is no significant difference, at $5 \%$ level, between the mean biomass observed of the two courses [25]. Furthermore if we examine the data of two surveys carried out over two consecutive days, the Wilcoxon test admits, at $5 \%$ level, that there is no significant differ-
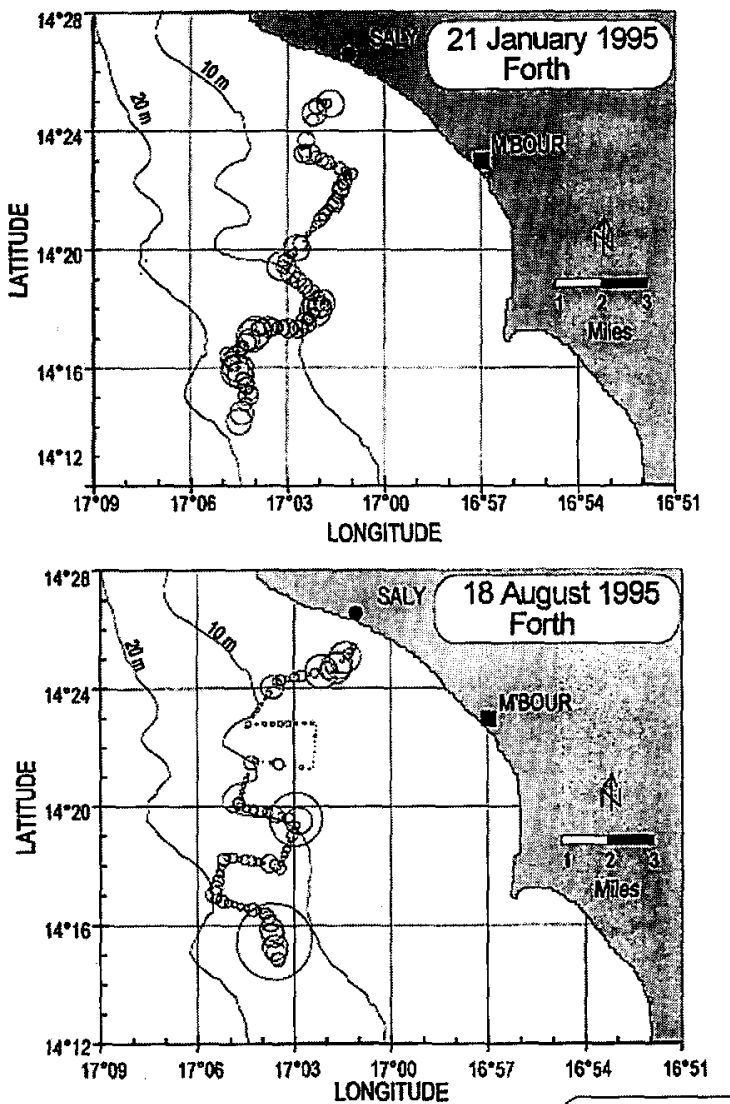

ence between the average acoustic biomass on the two days [25].

We examined data in order to test a hypothesis of the growth of the observed biomass over the course of the seasons (figure 3). The criteria is the average temperature of the surface water over a period of three days, determined by satellite observations supplied by the "Unité de Télédétection Informatique Sénégalaise". The hypothesis, at $5 \%$ level, using the Cox and Stuart test [25], is accepted.

Out of 20 variograms (figure 4), $85 \%$ show a flat rate, otherwise called "pure nugget effect", which represents an absence of spatial structure [18]. The echointegration runs are spatially independent of each other.

The three remaining variograms (14 February, 18 August return) are linear, with a strong nugget effect,
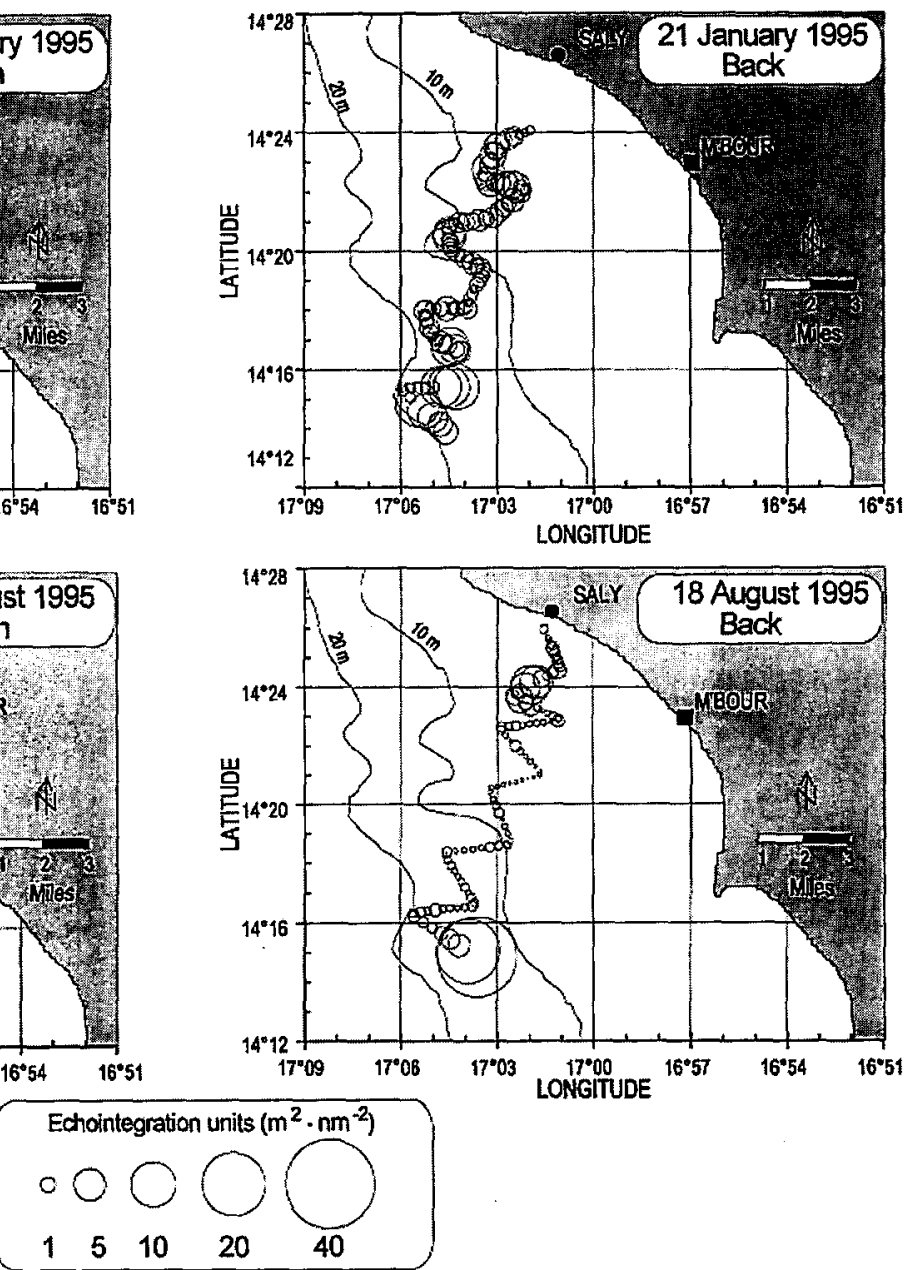

Figure 1. Examples of echointegration results $\left(\mathrm{m}^{2}\right.$. nautical mile $\left.\mathrm{e}^{-2}\right)(21$ January and 18 August 1995) for the strata surface - bottom; each circle is proportional to the acoustic biomass detected during a distance unit $(0.1$ nautical mile). 
Frequency (\%)

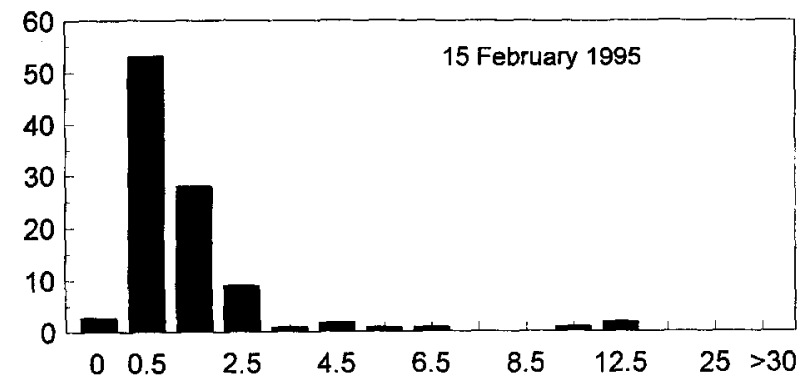

Frequency (\%)

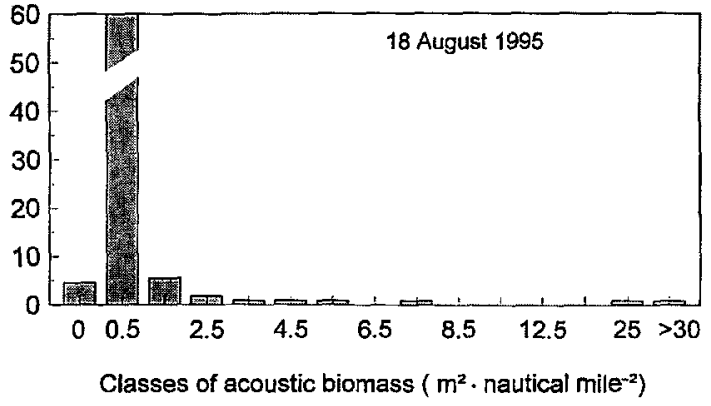

Figure 2. Examples of histograms of acoustic biomass classes, in echointegration units $\left(\mathrm{m}^{2}\right.$. nautical mile $\left.{ }^{-2}\right)$, for the strata surface - bottom, sample units of 0.1 nautical mile: surveys of the 15 February and 18 August 1995. The values are the median of each class, except for the first class (the zero values).

compared to the variance of the sample $(>50 \%)$. The values of the variable change abruptly at a very small scale [26], except in the case of 18 August where there is a much greater continuity (nugget effect close to zero).

\subsection{Target strength (T.S.) distribution from split- beam}

The target strength described here are for fish where body aspect in the beam is unknown, and used as a "field estimate of target strength" rather than an attempt to determine fish sizes. T.S. frequency distributions were established for the different surveys (figure 5). Single fish were distributed between $2 \mathrm{~m}$ depth and bottom. There is no significant relation between single fish depth and individual T.S. values. If we consider the median T.S., estimated for each survey, it remains very close from one survey to another; the difference is less than $2 \mathrm{~dB}$ (table $I$ ).

If we divide the T.S. into 3 categories of size (table $I I I)$, the medium class $(-34 \mathrm{~dB}$ to $-42 \mathrm{~dB})$ has the majority, but the percentages of the other classes vary in time. In particular "large" fish (greater then $-34 \mathrm{~dB}$ ) increase in May and August. The percentage of small fish strongly increases for the trip made on the 29 March. In the cold season, fish seems to be larger near the coast, whereas in the hot season the opposite is true (table II). March was the only month to show a lower modal T.S.

\section{DISCUSSION}

These results are too fragmentary to be considered as the normal fish population distribution, and have to be analysed only like a first indication of the spatial structures of fish population in the Senegalese coastal area. Thus, it is not possible to compare the distribution of acoustic biomass observed during these experiments with the maps described in literature $[2,1]$, as they only take into consideration zones of depths greater than $15 \mathrm{~m}$. The strongest concentrations are mapped near the coast in the cold season, whereas our results indicate the opposite.

The acoustic biomass detected is not significantly different between two consecutive surveys. Apart from 21 April, when surveys were along the coast, the estimated acoustic biomass of forth and back were very different (1.86 and 0.40 ), perhaps partly due to fish migrating with the tide.

The influence of schools on stock levels estimations has already been shown $[6,14]$. Their presence or absence can alter the average of estimations by a considerable amount. In shallow waters the problem is identical, but it appears that in zones close to the coast, schools are few.

It is difficult in the case of a population of multi-specific fish, such as that found in Senegalese waters, to address relationships between T.S. and real size. Despite the fact that this parameter is dependent on size and varies over the course of the seasons [16], we can still observe trends and try to make a size classification. Median T.S. vary slightly through the course of season, except in March. But this phenomena is perhaps induced by an under-sampling; there were only 105 targets, whereas in other cases the number is greater.

Acoustic observations are often biased by escape phenomena due to the reactions of the fish on the approach of the boat $[15,7]$. This behaviour is dependent on numerous factors linked with the environment (season, luminosity, etc.), fishing, types of boat, and the consequences upon the estimations of population and spatial distribution are obviously fundamental. In shallow waters this problem is even more important because the sampled layer is low and that the disturbances can affect the total amount of fish present. Avoidance can be divided into two categories - horizontal and vertical. In Gerlotto and Fréon's opinion [8] horizontal avoidance is minimal, as the schools escape in the axis of the boat, trapped by the shadow of the acoustic cone. According to Soria [22], fish dive at night only in the presence of distinct luminosity or 
Table I. Echointegration runs using the split-beam echosounder, in echointegration units $\left(\mathrm{m}^{2} \cdot\right.$ nautical mile $\left.{ }^{-2}\right)$.

\begin{tabular}{|c|c|c|c|c|c|c|c|}
\hline & Date & $\begin{array}{l}\text { Number } \\
\text { of runs }\end{array}$ & Max. & $\begin{array}{c}\text { Min. } \\
\mathrm{m}^{2} \text {.nautical mile }\end{array}$ & Mean & $\mathrm{SD}$ & SD/Mean \\
\hline Forth & 8 Dec. 1994 & & & & & & \\
\hline Back & Full moon +6 & 30 & 27.75 & 0.00 & 2.57 & 5.33 & 207 \\
\hline Forth & 18 Jan. 1995 & 74 & 61.56 & 0.00 & 3.13 & 7.85 & 250 \\
\hline Back & Full moon +2 & & & & & & \\
\hline Forth & 20 Jan. 1995 & 77 & 11.56 & 0.00 & 1.38 & 1.99 & 144 \\
\hline Back & Full moon +4 & 152 & 4.99 & 0.00 & 0.88 & 0.89 & 101 \\
\hline Forth & 21 Jan. 1995 & 95 & 5.46 & 0.00 & 1.25 & 1.16 & 92 \\
\hline Back & Full moon +5 & 104 & 10.33 & 0.25 & 1.88 & 1.97 & 104 \\
\hline Forth & 14 Feb. 1995 & 140 & 6.36 & 0.00 & 0.74 & 0.95 & 128 \\
\hline Back & Full moon - 1 & 187 & 5.81 & 0.00 & 0.82 & 1.10 & 134 \\
\hline Forth & 15 Feb. 1995 & 100 & 13.29 & 0.00 & 1.39 & 2.04 & 146 \\
\hline Back & Full moon & 46 & 2.00 & 0.00 & 0.53 & 0.48 & 90 \\
\hline Forth & 29 Mar. 1995 & 123 & 1.95 & 0.00 & 0.23 & 0.38 & 165 \\
\hline Back & Full moon +13 & 126 & 0.87 & 0.00 & 0.14 & 0.17 & 120 \\
\hline Forth & 30 Mar. 1995 & 117 & 0.60 & 0.00 & 0.05 & 0.10 & 200 \\
\hline Back & Full moon +14 & 142 & 0.27 & 0.00 & 0.07 & 0.06 & 85 \\
\hline Forth & 21 Apr. 1995 & 84 & 37.92 & 0.03 & 1.86 & 6.08 & 326 \\
\hline Back & Full moon +5 & 103 & 12.42 & 0.00 & 0.40 & 1.70 & 425 \\
\hline Forth & 30 May 1995 & 51 & 4.73 & 0.05 & 0.56 & 0.76 & 135 \\
\hline Back & Full moon +15 & 124 & 15.08 & 0.00 & 0.50 & 1.62 & 324 \\
\hline Forth & 18 Aug. 1995 & 112 & 28.61 & 0.00 & 0.92 & 3.08 & 334 \\
\hline Back & Full moon +8 & 117 & 31.66 & 0.00 & 1.00 & 3.69 & 369 \\
\hline
\end{tabular}

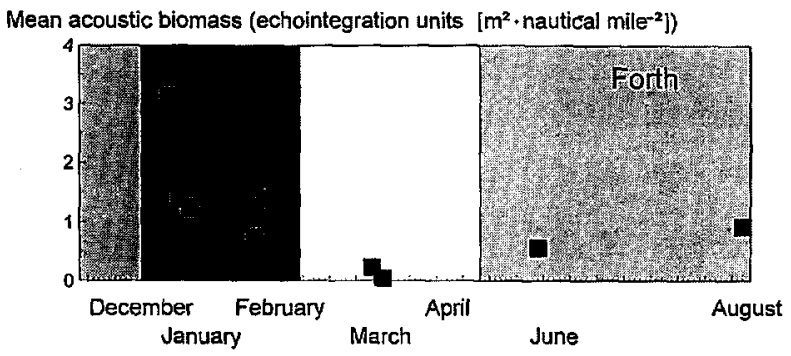

Mean acoustic biomass (echointegration units $\left[\mathrm{m}^{2} \cdot\right.$ nautical mile-2 $]$ )

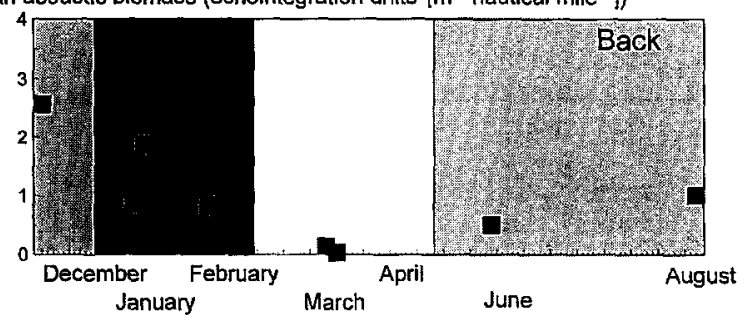

Figure 3. Evolution of mean acoustic biomass, in echointegration units $\left(\mathrm{m}^{2}\right.$. nautical mile $\left.{ }^{-2}\right)$. The surfaces in white correspond to the season with a water surface temperature less than $20^{\circ} \mathrm{C}$, in grey more than $24^{\circ} \mathrm{C}$, and in black between $20^{\circ} \mathrm{C}$ and $24^{\circ} \mathrm{C}$.
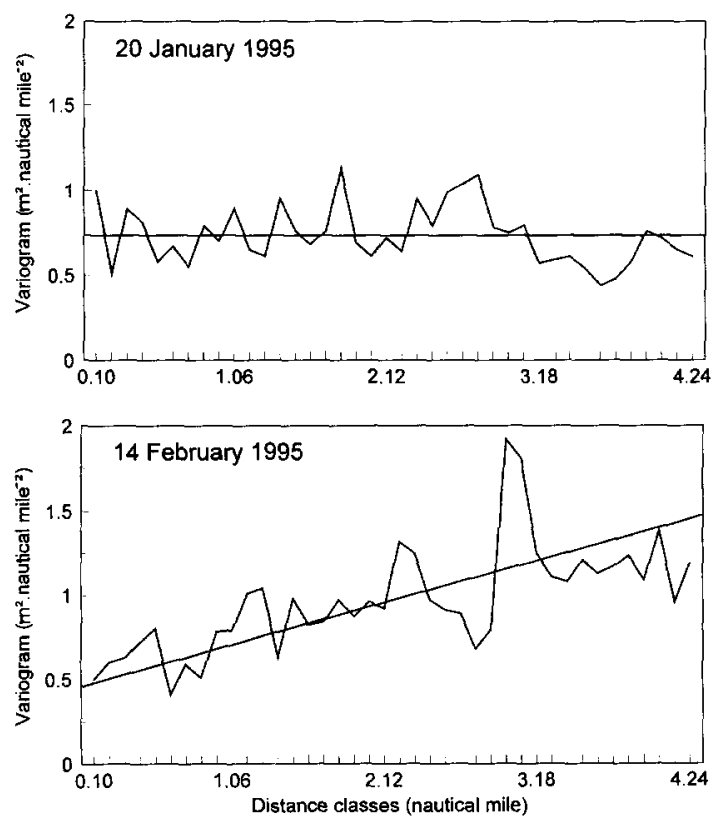

Figure 4. Examples of variograms (echointegration units: $\mathrm{m}^{2}$ - nautical mile $^{-2}$ ) calculated for all the strata and fitted model [flat variogram (20 January 1995) and linear variogram (14 February 1995)]. 

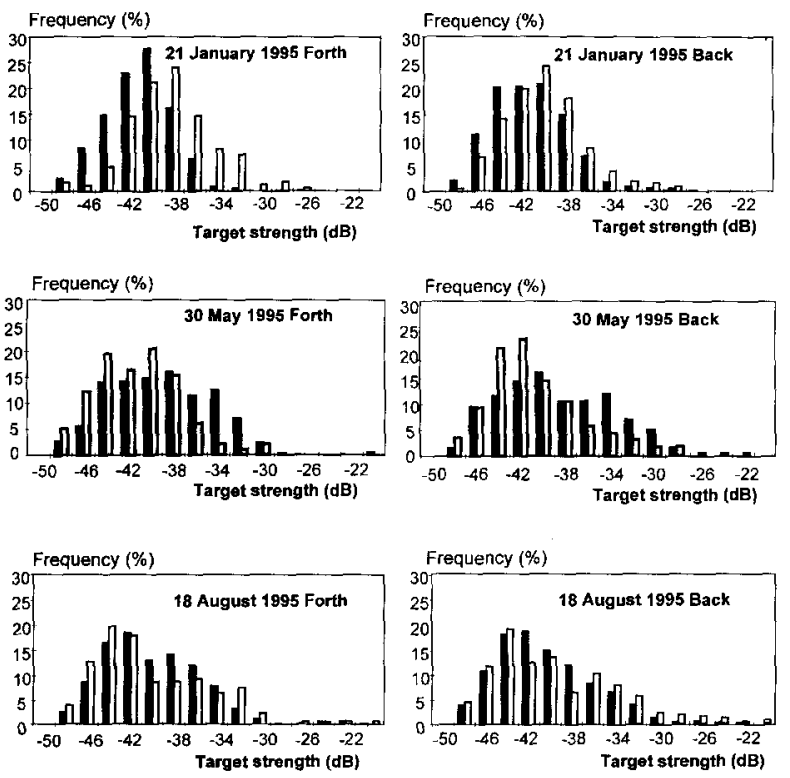

Figure 5. Examples of target strength distributions of single fish by classes of $2 \mathrm{~dB}$, forth and back, depth less than $10 \mathrm{~m}$ (white bar) and more than $10 \mathrm{~m}$ (black bar), from split-beam data (2I January, 30 May and 18 August 1995).

large audible disturbances. In this case, when the fish dive, the incidental angle will alter and the T.S. will have a lower average value [12].

Within the different sets of data it is not noticeable that the T.S. are weaker in the surface layers, where the avoidance behaviour should be greater. The different analyses of avoidance behaviour are difficult to quantify in terms of percentage of population which escape to detection in vertical emission. We can only conclude on a phenomenon which underestimates the biomass present, but which only affects a fraction of the biomass, particularly for schools.

Because of problems caused by inaccurate TVG start and a transceiver delay, results of EY500 sounder in the near layers have to be treated with caution [17]. Furthermore problems can come from badly discerned targets (i.e. one target confused with two close targets) [24], or from a position within the range giving very variable results (slight movement of the phase, fish seen partially, targets considered as spot despite the distance to the transducer is of the same size category). The narrow angle of the transducer only allows a short sighting of the fish. The discriminatory criteria of individual targets with a minimum of two emissions, is obviously weak, but operations in shallow depths prevents the increase of this criteria. In these data, more than $70 \%$ of detected targets were hit only twice. With larger discriminatory criteria, the number of targets would be insignificant.

The use of the transducer on a towed body would improve data acquisition. A multi-range RESON SEABAT 6012 sonar [23], frequency $455 \mathrm{kHz}$, pulse length $0.06 \mathrm{~ms}$, composed of 60 transducers of $1.5^{\circ}$ at $-3 \mathrm{~dB}$ hence covering an area of $90^{\circ}$ in the vertical plane and $15^{\circ}$ horizontally was used simultaneously with the SIMRAD EY500 sounder for the January to March surveys. The sonar RESON partially solves avoidance and escape phenomena by observing fish

Table II. Median target strength (in dB) for all the surveys, when the number of single fish detections is more than 100 .

\begin{tabular}{|c|c|c|c|c|c|c|c|c|}
\hline Depth & 18 Jan. & $20 \mathrm{Jan}$. & $21 \mathrm{Jan}$. & 29 Mar. & 30 Mar. & $21 \mathrm{Apr}$. & 30 May & 18 Aug. \\
\hline $\begin{array}{l}\text { Forth } \\
<10 \mathrm{~m}\end{array}$ & -39.5 & -38.8 & -39.2 & -43.8 & & & -422 & -411 \\
\hline$>10 \mathrm{~m}$ & -40.6 & -41.6 & -42.0 & -43.7 & & & -39.9 & -40.9 \\
\hline \multicolumn{9}{|l|}{ Back } \\
\hline$<10 \mathrm{~m}$ & & -41.5 & -41.0 & -44.3 & -42.1 & -42.7 & -41.6 & -40.4 \\
\hline$>10 \mathrm{~m}$ & & -42.0 & -42.2 & -43.8 & -42.2 & & -39.8 & -41.5 \\
\hline
\end{tabular}

Table III. Percentage of detected target for target strength classes defined for all the surveys: Large $\leq-34 \mathrm{~dB} ;-34 \mathrm{~dB}<\mathrm{medium}<-44 \mathrm{~dB}$; small $\geq-44 \mathrm{~dB}$.

\begin{tabular}{|c|c|c|c|c|c|c|c|c|}
\hline $\begin{array}{l}\text { Target strength } \\
\text { classes }\end{array}$ & 18 Jan. & $20 \mathrm{Jan}$ & 21 Jan. & 29 Mar. & 30 Mar. & $21 \mathrm{Apr}$. & 30 May & 18 Aug. \\
\hline \multicolumn{9}{|l|}{ Forth } \\
\hline Large & 11.5 & 14.6 & 4.5 & 0.5 & & & 18.9 & 15.1 \\
\hline Medium & 72.2 & 68.5 & 73.0 & 51.4 & & & 56.4 & 54.6 \\
\hline Small & 16.2 & 16.7 & 22.4 & 48.1 & & & 24.7 & 30.3 \\
\hline \multicolumn{9}{|l|}{ Back } \\
\hline Large & & 5.5 & 5.0 & 1.2 & 2.7 & 2.5 & 18.6 & 15.1 \\
\hline Medium & & 64.3 & 65.0 & 42.8 & 67.0 & 65.0 & 52.8 & 51.2 \\
\hline Small & & 30.1 & 30.0 & 56.0 & 30.4 & 32.5 & 28.5 & 33.6 \\
\hline
\end{tabular}


and schools at a certain distance from the boat. We found that present technology of the multi-range sonar posed interpretation problems, but is very promising in fish population studies in shallow waters, as in the case of the elliptical transducer. These new developments mean that shallow waters will be more easily studied in the future.

\section{CONCLUSION}

The improvements of recent technology in sonar mean that even in shallow waters acoustic techniques allow a picture of the fish populations present, in terms of acoustic biomass and acoustic size distribution. Even if some difficulties have been demonstrated by Ona et al. [17] in EY500 data in the near layers, we can try to analyse them, with caution, and knowing that there are some potential bias. In examining the T.S. data by class, we can obtain a rough idea of size structures and their evolution. The image obtained is biased by the escape behaviour of the fish which is only partially known, especially its variability in time when carrying out surveys in different seasons.

The fish biomass observed in these areas are very variable with time, with a pronounced difference between the seasons. It seems that the biomass present remain relatively stable over short periods. Size distribution remains also relatively constant during the course of an annual cycle, whereas migration phenomena linked to reproduction led us to imagine other schemas; there will be a renewal of fish on the coast and fish are found everywhere. Surveys in geographical areas stretched out for example, over a week during "characteristic" seasonal periods, will enable better exploration of these spatial structures and compare with the artisanal catches.

\section{Acknowledgements}

We wish to thank Mr D. Touré, director of Centre de Recherches Océanographique de Dakar-Thiaroye, for giving us the opportunity to work with his Institute; B. Samb for his help in the realisation of this work, and I Sow for his very helpful participation of all field experiments.

\section{REFERENCES}

[1] Barry-Gérard M., Kebe M., Thiam M., Exploitation des ressources halieutiques côtières dans les eaux sous juridiction sénégalaise, in: Actes de l'Atelier de Gorée du 27-29 juillet 1992, Gestion des ressources côtières et littorales du Sénégal. Diaw A. T. (ed.), UICN-ISRAIFAN Dakar, 1993, pp. 291-310.

[2] Boëly T., Chabanne J., Fréon P., Schémas migratoires, aires de concentrations et périodes de reproduction des principales espèces de poissons pélagiques côtiers dans la zone sénégalo-mauritanienne, in: Rapport du groupe de travail ad hoc sur les poissons pélagiques côtiers ouest-africains de la Mauritanie au Liberia $\left(26^{\circ} \mathrm{N}\right.$ à $\left.5^{\circ} \mathrm{N}\right)$. Dakar, Sénégal COPACE/PACE sér. 78.10, 1978, pp. 63-70.

[3] Duncan A., Kubecka J., Patchiness of longitudinal fish distributions in a river as revealed by a continous hydroacoustic survey, ICES J. Mar. Sci. 53 (1996) 161165.

[4] Foote K.H., Knudsen H.P., Vestnes G., MacLennan D.N., Simmonds E.J., Calibration of acoustic instruments for fish density estimation: a pratical guide, ICES Coop. Res. Rep., 1987, 144 p.

[5] Fréon P., Réponses et adaptations des stocks de clupéidés d'Afrique de l'Ouest à la variabilité du milieu et de l'exploitation : analyse et réflexion à partir de l'exemple du Sénégal. Thèse dr. Etat, Univ. AixMarseille II (1988) 284 p.
[6] Fréon P., Gerlotto F., Misund O.A., Consequences of fish behaviour for stock assessment, ICES Mar Sci. Symp. 196 (1993) 190-195.

[7] Fréon P., Soria M., Mullon C., Gerlotto F., Diurnal variation in fish density estimates during acoustic surveys in relation to spatial distribution and avoidance reaction, Aquat. Living Resour. 6 (1993) 221-234.

[8] Gerlotto F., Fréon P., Some elements on vertical avoidance of fish schools to vessel acoutic surveys, Fish. Res. 14 (1990) $251-259$.

[9] Gerlotto F., Claro R., Hernandez-Corujo C., GarciaArteuga J.P., Una metodologia para la evaluacion de los recursos pesqueros por hidroacustica en aguas someras, Sci. Mar. 56 (1992) 309-319.

[10] Guillard J., Boët P., Gerdeaux D., Roux P., Application of mobile acoustic techniques fish survey in shallow water: the river Seine, Regul. Riv. Res. Manag. 9 (1994) 121-126.

[11] Kubecka J., Duncan A., Butterworth A., Echo counting or echo integration for fish biomass assessment in shallow waters, Proc. Europ. Conf. Underwater Acoustics. Luxembourg, 14-18 sept. 1992. Weydert M. (ed.), Elsevier, 1992, pp. 129-132.

[12] Love R.H., Target strength of an individual fish at any aspect, J. Acoust. Soc. Am. 62 (1977) 1397-1403.

[13] MacLennan D.N., Simmonds E.J., Fisheries acoustics. Chapman and Hall, London, 1992, 325 p.

[14] Marchal E., Petitgas P., Precision of acoustic fish abundance estimates: separating the number of schools from the biomass in the schools, Aquat. Living Resour. 6 (1993) 211-219. 
[15] Olsen K.A., Petters J., Lovik A., Observed fish reactions to a surveying vessel with special reference to herring, cod, capelin and polar cod, FAO Fish. Rep. 300 (1983) $131-138$.

[16] Ona E., Physiological factors causing natural variations in acoustic target strength of fish, J. Mar. Biol. Assoc. U.K. 70 (1990) 107-127.

[17] Ona E., Zhao X., Svellingen I., Foote K.G., Some pitfalls of short-range standard calibration, ICES/CM/ B:36, 1996, $14 \mathrm{p}$.

[18] Petitgas P., Geostatistics for fish stock assessments: a review and an acoustic application, ICES J. Mar. Sci. 50 (1993) 285-298.

[19] Petitgas P., Levenez J.J., Relationship between echogram structure, environment and biomass in tropical waters, ICES J. Mar. Sci. 53 (1996) 147-153.

[20] Petitgas P., Prampart A., EVA : Estimation variance, logiciel de Géostatistique pour l'analyse structurale et les calculs de variance, Editions de l'ORSTOM, log Orstom, Paris, 1995.

[21] SIMRAD, SIMRAD EY500 Portable scientific echo sounder, SIMRAD Subsea P2473E, 1994, pp. 17-31.

[22] Soria M., Structure et stabilité des bancs et agrégations de poissons pélagiques côtiers tropicaux : application halieutique, Thèse dr. Sci., Univ. Rennes I, 1994, 284 p.

[23] Soria M., Fréon P., Gerlotto F., Analysis of influence on spatial behaviour of fish schools using a multi-beam sonar and consequences on biomass estimates by echosounder, ICES J. Mar. Sci. 53 (1996) 453-458.

[24] Soule M.A., Barange M., Hampton I., Evidence of bias in estimates of target strength obtained with a splitbeam echo-sounder, ICES J. Mar. Sci. 52 (1995) 139144.

[25] Sprent P., Pratique des statistiques non paramétriques. INRA, Paris, 1992, 294 p.

[26] Wackernagel H., Multivariate geostatistics, SpringerVerlag, Berlin, 1995, 256 p. 